\title{
Development of $\mathrm{Bi}_{2} \mathrm{~W}_{1-\mathrm{x}} \mathrm{Mo}_{\mathrm{x}} \mathrm{O}_{6} /$ Montmorillonite nanocomposite as efficient catalyst for photocatalytic desulfurization
}

\author{
Xiazhang $\mathrm{Li}^{\mathrm{a}, \mathrm{b}, \mathrm{c}, *}, \quad$ Feihong $\mathrm{Li}^{\mathrm{a}}, \quad$ Xiaowang $\mathrm{Lu}^{\mathrm{a}}, \quad$ Shixiang $\mathrm{Zuo}^{\mathrm{a}}$, Chao $\mathrm{Yao}^{\mathrm{a}, \mathrm{b}, *}$, \\ Chaoying $\mathrm{Ni}^{\mathrm{c}}$
}

\begin{abstract}
A novel $\mathrm{Bi}_{2} \mathrm{~W}_{1-\mathrm{x}} \mathrm{Mo}_{\mathrm{x}} \mathrm{O}_{6} /$ Montmorillonite (MMT) nanocomposite was prepared by one-pot hydrothermal method. XRD, TEM, Raman, UV-vis, FT-IR, PL and XPS were employed to characterize the nanocomposites. The photocatalytic desulfurization properties of $\mathrm{Bi}_{2} \mathrm{~W}_{1-\mathrm{x}} \mathrm{Mo}_{\mathrm{x}} \mathrm{O}_{6} / \mathrm{MMT}$ nanocomposites were performed by oxidizing dibenzothiophene (DBT) in the model oil under visible light irradiation. Results indicate that the molar fraction of Mo doping has critical impact on the desulfurization rate. Adequate Mo doping may form well-defined "solid solution/co-precipitation" heterostructure of $\mathrm{Bi}_{2} \mathrm{~W}_{1-\mathrm{x}} \mathrm{Mo}_{\mathrm{x}} \mathrm{O}_{6} / \mathrm{Bi}_{2} \mathrm{MoO}_{6}$, which enhances the visible light absorption efficiency and promotes the
\end{abstract}


separation rate of photogenerated electron-hole pairs, thus leads to the improved photocatalytic desulfurization performance. The desulfurization rate of the model oil can reach $95 \%$ when the molar fraction $\mathrm{x}$ is 0.7 under visible light irradiation for $3 \mathrm{~h}$.

Keywords: Clay; $\mathrm{Bi}_{2} \mathrm{WO}_{6} ; \quad$ Heterostructure; Nanocomposite; Photocatalysis; Desulfurization

\section{Introduction}

Atmospheric haze, acid rain and other environmental issues have strong association with $\mathrm{SO}_{\mathrm{x}}$, a product of combustion of sulfur compounds existing in fuels. It is therefore essential to develop technologies for deep desulfurization of fuels $[1,2]$. As a conventional method, hydrodesulfurization (HDS) has been extensively applied to remove sulfur-containing substances. However, high temperature and pressure as well as expensive hydrogen are needed in the process of HDS [3-5]. Meanwhile, it is difficult for HDS to satisfy the demands of deep desulfurization because of the stability of DBT and derivatives [6]. For instance, 4, 6-dimethyl dibenzothiophene (4, 6-DMDBT) is hard to be abated under hydrogenation [7-9]. To save energy and cost, extractive desulfurization [10], biodesulfurization [11], adsorptive desulfurization [12] and oxidative desulfurization $[13,14]$ have been employed to remove sulfur compounds from model oil in the last few years. In 
particular as one of the most cheap and efficient desulfurization strategy, photocatalytic oxidative desulfurization has drawn much attention. Lu et al. [15] prepared $\mathrm{CeO}_{2} / \mathrm{TiO}_{2}$ nanotube arrays by anodization combined with microwave synthesis and found that over $90 \%$ of benzothiophene could be removed under visible light irradiation. Mandizadeh et al. [16] obtained $\mathrm{BaFe}_{2} \mathrm{O}_{4}$ by hydrothermal method demonstrating that the removal of dibenzothiophene by photocatalytic oxidative desulfurization reached as high as $96.6 \%$.

Nevertheless, developing cost-effective and more efficient visible light photocatalytic material for the abatement of sulfur compounds remains as an imperative challenge. Layered $\mathrm{Bi}_{2} \mathrm{WO}_{6}$ has excellent chemical and thermal stability $[17,18]$. However, its low absorption rate of sunlight and high recombination of photogenerated carriers greatly impede its photocatalytic performance [19]. In most cases, $\mathrm{Bi}_{2} \mathrm{WO}_{6}$ is used in combination with other semiconductors in order to solve the above drawbacks. For instance, Zhang et al. [20] synthesized $\mathrm{Bi}_{2} \mathrm{WO}_{6} / \mathrm{TiO}_{2}$ composites which were in favor of accelerating the separation of photogenerated carriers thus enhancing the photocatalytic activity. Liu et al. [21] fabricated $\mathrm{ZnO} / \mathrm{Bi}_{2} \mathrm{WO}_{6}$ composites which prevented the recombination of electron-holes. $\mathrm{Bi}_{2} \mathrm{MoO}_{6}$ is a layer-structured material which possesses narrower band gap than its analogous counterpart $\mathrm{Bi}_{2} \mathrm{WO}_{6}$ [22]. It is reported that $\mathrm{Bi}_{2} \mathrm{WO}_{6}$ and 
$\mathrm{Bi}_{2} \mathrm{MoO}_{6}$ may form coherent nanocomposite to improve the photocatalytic performance due to the fact that the $\mathrm{Bi}_{2} \mathrm{Mo}_{\mathrm{x}} \mathrm{W}_{1-\mathrm{x}} \mathrm{O}_{6}$ heterojunction structure formed by two-step heating treatment improves the separation of photogenerated carriers, and narrows the band gap [23]. This paper reports, for the first time to the best of our knowledge, the photocatalytic oxidative enhancement of the resulting compound through the incorporation of Mo into $\mathrm{Bi}_{2} \mathrm{WO}_{6}$.

Moreover, the agglomeration of nanoparticles often occurs during the synthetic progress. The adsorption property of support may largely address the above problem. For instance, we have previously prepared attapulgite- $\mathrm{CeO}_{2} / \mathrm{MoS}_{2}$ ternary composite for photocatalytic oxidative desulfurization of model oil [24]. Except for attapulgite, plenty of other supports have been researched, including graphene, clay minerals, zeolites [25-27] etc. As a typical layered clay minerals, MMT possesses large surface area and chemical stability, which are adopted to control particle size and avoid particle agglomeration [28, 29]. Wu et al. [30] prepared $\mathrm{CaO}_{2}-\mathrm{MMT}$ nanocomposites and found that the $\mathrm{CaO}_{2}$ particles were well dispersed on the surface of MMT with the average size around $10 \mathrm{~nm}$.

Herein, in this work, we synthesize $\mathrm{Bi}_{2} \mathrm{~W}_{1-\mathrm{x}} \mathrm{Mo}_{\mathrm{x}} \mathrm{O}_{6} / \mathrm{MMT}$ composite photocatalysts via a one-pot hydrothermal method in an attempt to form $\mathrm{Bi}_{2} \mathrm{~W}_{1-\mathrm{x}} \mathrm{Mo}_{\mathrm{x}} \mathrm{O}_{6} / \mathrm{Bi}_{2} \mathrm{MoO}_{6}$ heterostructure by rational tuning the doping 
fraction of Mo. The visible light absorption range is anticipated to be extended, and the recombination of photogenerated carriers is expected to be prohibited. The molar fraction of Mo doping influencing the photocatalytic oxidative desulfurization performance is investigated by degrading DBT in the model oil.

\section{Experimental section}

\subsection{Materials}

Bismuth nitrate $\left(\mathrm{Bi}\left(\mathrm{NO}_{3}\right)_{3} \cdot 5 \mathrm{H}_{2} \mathrm{O}\right)$ was obtained from Medicine Group Chemical Reagent Co., Ltd. Sodium molybdate $\left(\mathrm{Na}_{2} \mathrm{MoO}_{4} \cdot 2 \mathrm{H}_{2} \mathrm{O}\right)$, Sodium tungstate $\left(\mathrm{Na}_{2} \mathrm{WO}_{4} \cdot 2 \mathrm{H}_{2} \mathrm{O}\right)$ and hydrogen peroxide $\left(\mathrm{H}_{2} \mathrm{O}_{2}\right)$ were afforded by Lingfeng Chemical Co., Ltd. DBT $\left(\mathrm{C}_{12} \mathrm{H}_{8} \mathrm{~S}\right)$ was purchased from Aladdin Bio-Chem Technology Co., Ltd. N-N dimethyl formamide (DMF, $\left.\mathrm{HCON}\left(\mathrm{CH}_{3}\right)_{2}\right)$ and octane $\left(\mathrm{C}_{8} \mathrm{H}_{18}\right)$ were obtained from Shengqiang Chemical Co., Ltd.

2.2Synthesis of $\mathrm{Bi}_{2} \mathrm{~W}_{1-\mathrm{x}} \mathrm{Mo}_{\mathrm{x}} \mathrm{O}_{6} / \mathrm{MMT}$

$\mathrm{Bi}_{2} \mathrm{~W}_{1-\mathrm{x}} \mathrm{Mo}_{\mathrm{x}} \mathrm{O}_{6} / \mathrm{MMT}$ samples were prepared via a one-pot hydrothermal method. In a representative reaction, $2 \mathrm{mmol}$ $\mathrm{Bi}\left(\mathrm{NO}_{3}\right)_{3} \cdot 5 \mathrm{H}_{2} \mathrm{O}, 2 \mathrm{mmol} \mathrm{Na}_{2} \mathrm{WO}_{4} \cdot 2 \mathrm{H}_{2} \mathrm{O}$ and $\mathrm{Na}_{2} \mathrm{MoO}_{4} \cdot 2 \mathrm{H}_{2} \mathrm{O}$ with W/Mo molar fractions of $9 / 1,8 / 2,7 / 3,6 / 4,5 / 5,4 / 6,3 / 7,2 / 8$ and 1/9 were dissolved into $15 \mathrm{~mL}$ deionized water with magnetic stirring. $1 \mathrm{~g}$ MMT was dissolved into $20 \mathrm{~mL}$ deionized water. Whereafter, the above 
solutions were transferred into a $100 \mathrm{~mL}$ Teflon-lined stainless steel autoclave, and held at $180^{\circ} \mathrm{C}$ for $24 \mathrm{~h}$. Then the products were washed several times by deionized water and ethanol, and subsequently dried at $80^{\circ} \mathrm{C}$ for $12 \mathrm{~h}$.

\subsection{Materials characterization}

The powder X-ray diffraction (XRD) was characterized with a $\mathrm{D} / \max 2500 \mathrm{PC}$ diffractometer radiated by $\mathrm{Cu} \mathrm{K} \alpha$ under room temperature. Tube voltage and current were $40 \mathrm{kV}$ and $100 \mathrm{~mA}$, continuous scanning speed was $6 \% \mathrm{~min}$, scanning speed was $0.02 \%$, and scan range was $5-80^{\circ}$. The morphology and size of grain were observed by a JEM-2100 transmission election microscope (TEM) equipped with Gatan $832 \mathrm{CCD}$ operating at a voltage of $200 \mathrm{kV}$. Ultraviolate visible diffuse reflectance spectra (UV-vis DRS) were obtained using a UV-2500 Shimadzu UV-vis spectrophotometer with scanning range from 200 nm-800 nm. Raman spectra were measured with a Renishaw spectrometer, and the excitation wavelength was $514 \mathrm{~nm}$. FT-IR spectra were obtained with a Nicolet vatar370 with scanning wavelength range from $500 \mathrm{~cm}^{-1}$ to $4000 \mathrm{~cm}^{-1}$. The photoluminescence (PL) spectra were collected with a PerkinElmer LS45 at room temperature. The X-ray photoelectron spectroscopy (XPS) characterization was performed with a PerkinElmer PHI 5300 XPS spectrometer equipped with $\mathrm{Mg} \mathrm{K} \alpha$ under a position of $284.6 \mathrm{eV}$ for C $1 \mathrm{~s}$. 


\subsection{Photocatalytic desulfurization}

The desulfurization process of model oil was carried out by a visible light catalytic reaction apparatus equipped with a $300 \mathrm{~W}$ xenon lamp as simulative sunlight source to verify that only irradiated by visible light without any wavelengths shorter than $420 \mathrm{~nm}$. The model oil with sulfur content of 200 ppm was prepared by dissolving 0.4031 g DBT into 500 $\mathrm{mL}$ of octane. Then adequate amount of catalyst were added to the above solution, and then transferred into the apparatus. The photocatalytic desulfurization reaction was performed in the dark with constant magnetic stirring for 30 min firstly. $30 \mathrm{wt} \% \mathrm{H}_{2} \mathrm{O}_{2}$ was added to the mixture (the optimal S/O molar ratio was 1:4). Subsequently, the reaction system was irradiated by $300 \mathrm{~W}$ xenon lamp. The degraded samples were collected twice an hour, then DMF was added into the samples to extract the supernatant liquid. Eventually, the top layer model oil was collected, which was used to detect sulfur content with a sulfur determinator (THA2000S), and the desulfurization rate D was measured in accordance with the following formula:

$$
\mathrm{D}=\left(1-\mathrm{C} / \mathrm{C}_{0}\right) \times 100 \%
$$

where $\mathrm{C}_{0}$ and $\mathrm{C}$ are the initial and the final sulfur content, respectively.

\section{Results and discussion}

\subsection{XRD analysis}


Fig.1 states the XRD patterns of $\mathrm{Bi}_{2} \mathrm{~W}_{1-\mathrm{x}} \mathrm{Mo}_{\mathrm{x}} \mathrm{O}_{6} / \mathrm{MMT}$ and MMT. The diffraction peaks at $5.64^{\circ}$ and $22.3^{\circ}$ are assigned to (001) and (110) (JCPDS 50-1496) of pure MMT. As can be seen, reflection observed at $28.3^{\circ}, 32.5^{\circ}, 47.5^{\circ}$ and $56.1^{\circ}$ corresponds to the natural diffraction of the (131), (200), (026) and (313) planes of the pure $\mathrm{Bi}_{2} \mathrm{WO}_{6}$ (JCPDS 79-2381) [31]. The high and sharp diffraction peak shows well-defined crystallinity. It is worth mentioning that the product may form solid solution phase when $\mathrm{x}$ is less than 0.5 , however with further increasing content of Mo doping, four diffraction peaks assigned to (131), (002), (060), (331) of the plane of $\mathrm{Bi}_{2} \mathrm{MoO}_{6}$ in the composite appear at $28.6^{\circ}, 32.3^{\circ}, 33.1^{\circ}, 47.2^{\circ}$. It is noticed that the (131) peak of $\mathrm{Bi}_{2} \mathrm{WO}_{6}$ at $28.3^{\circ}$ shifts to lower angle with increasing of Mo doping, which may be due to the substitution of Mo for $\mathrm{Bi}_{2} \mathrm{WO}_{6}$, leading to the lattice distortion and more structural defects. 


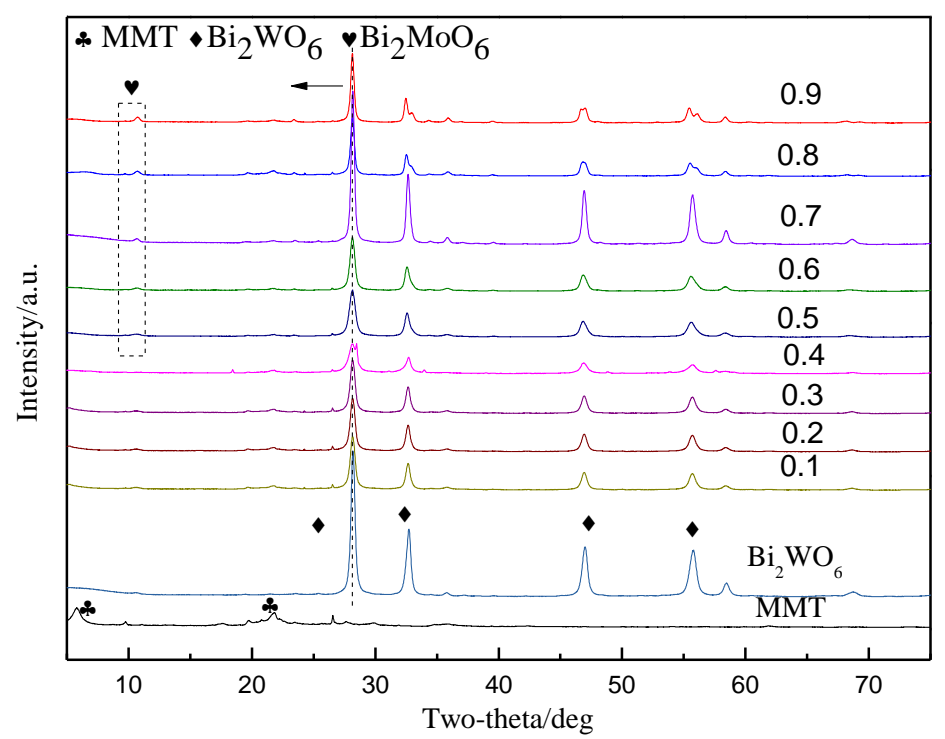

Fig.1. XRD patterns of $\mathrm{Bi}_{2} \mathrm{~W}_{1-\mathrm{x}} \mathrm{Mo}_{\mathrm{x}} \mathrm{O}_{6} / \mathrm{MMT}$ with various molar fractions

\subsection{Raman analysis}

The Raman spectra of $\mathrm{Bi}_{2} \mathrm{~W}_{1-\mathrm{x}} \mathrm{Mo}_{\mathrm{x}} \mathrm{O}_{6} / \mathrm{MMT}$ with various molar fractions of Mo are observed in Fig.2. The band located at $170 \mathrm{~cm}^{-1}$ is ascribed to Si-O stretching vibration of MMT. The band in the range of 250-500 $\mathrm{cm}^{-1}$ and 700-900 $\mathrm{cm}^{-1}$ correspond to W-O bending vibration [32]. There are no new peaks present when $\mathrm{x}$ is lower than 0.5. However, the band locates at $1600 \mathrm{~cm}^{-1}$ is assigned to Mo-O stretching vibration when $\mathrm{x}$ is more than 0.6 [33]. In combination with the XRD analysis, the composite forms $\mathrm{Bi}_{2} \mathrm{~W}_{1-\mathrm{x}} \mathrm{Mo}_{\mathrm{x}} \mathrm{O}_{6}$ solid solution phase when $\mathrm{x}$ is between 0.1 and 0.5. However, the peak of $\mathrm{Bi}_{2} \mathrm{MoO}_{6}$ starts to appear when $\mathrm{x}$ is higher than 0.5 . 


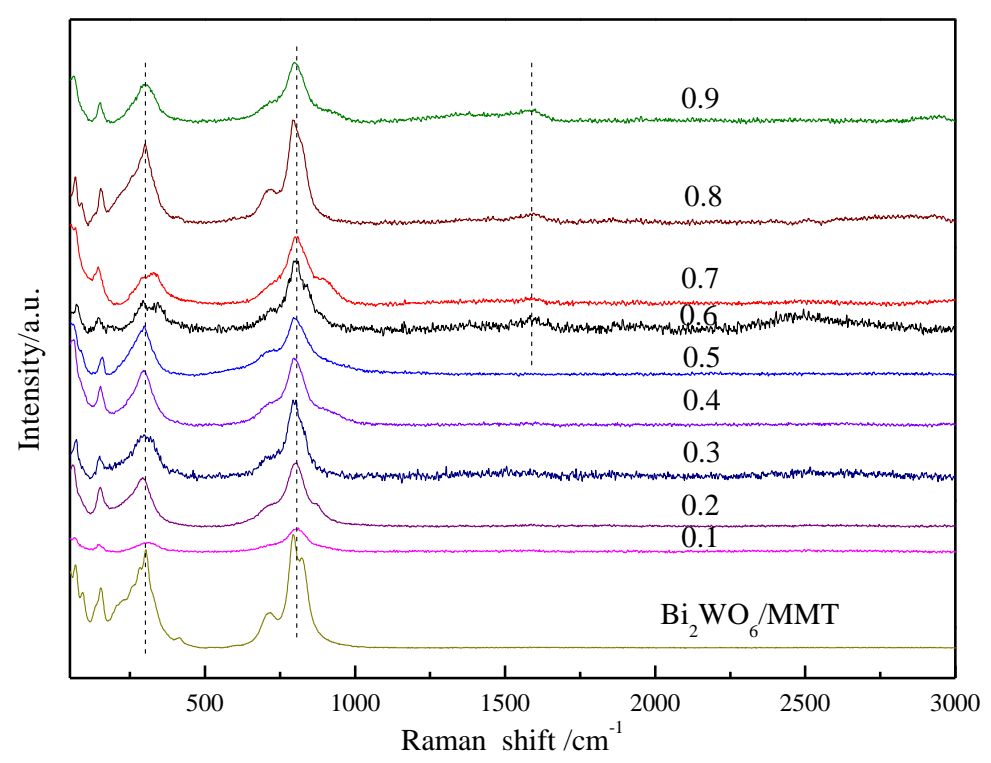

Fig. 2. Raman spectra of $\mathrm{Bi}_{2} \mathrm{~W}_{1-\mathrm{x}} \mathrm{Mo}_{\mathrm{x}} \mathrm{O}_{6} / \mathrm{MMT}$ with various molar fractions of Mo.

\subsection{TEM analysis}

The morphology of $\mathrm{Bi}_{2} \mathrm{~W}_{1-\mathrm{x}} \mathrm{Mo}_{\mathrm{x}} \mathrm{O}_{6} / \mathrm{MMT}$ is shown in Fig.3. It is noticed that the raw MMT shows layered structure with the absence of other impurities on the surface (Fig. 3a). Fig. 3b represents the prepared composite without any pretreatment, which can be found that there is a severe aggregation of nanoparticles on the raw MMT surface, suggesting that the untreated MMT cannot act as an appropriate support due to its thick layer. On the contrary, Fig. 3c shows the prepared composite with exfoliated MMT as a support. The well dispersed semiconductor nanoflakes on MMT surface were observed. The layer-to-layer distance of MMT can be extended by the exfoliated process. The inset is electron diffraction pattern, which shows a clear diffraction ring demonstrating that the composite has high crystallinity. Fig. 3d shows obvious lattice fringe of (002) plane for $\mathrm{Bi}_{2} \mathrm{WO}_{6}$ corresponding to a 
distance of $0.275 \mathrm{~nm}$, suggesting the formation of solid solution of Mo doped $\mathrm{Bi}_{2} \mathrm{WO}_{6}$ with the absence of other compounds. The lattice spacing of $0.223 \mathrm{~nm}$ correspond to (131) plane of $\mathrm{Bi}_{2} \mathrm{MoO}_{6}$ in addition to (002) plane of $\mathrm{Bi}_{2} \mathrm{WO}_{6}$ appears in Fig. 3e. The close integration of $\mathrm{Bi}_{2} \mathrm{WO}_{6}$ and $\mathrm{Bi}_{2} \mathrm{MoO}_{6}$ give rise to the formation of coherent heterostructure. Energy-dispersive spectroscopy (EDS) pattern demonstrates the existence of $\mathrm{Bi}, \mathrm{W}, \mathrm{Mo}, \mathrm{Si}, \mathrm{Mg}, \mathrm{Al}$ elements (Fig.3f). Among of them, $\mathrm{Si}, \mathrm{Mg}$ and $\mathrm{Al}$ are assigned to MMT substrate.
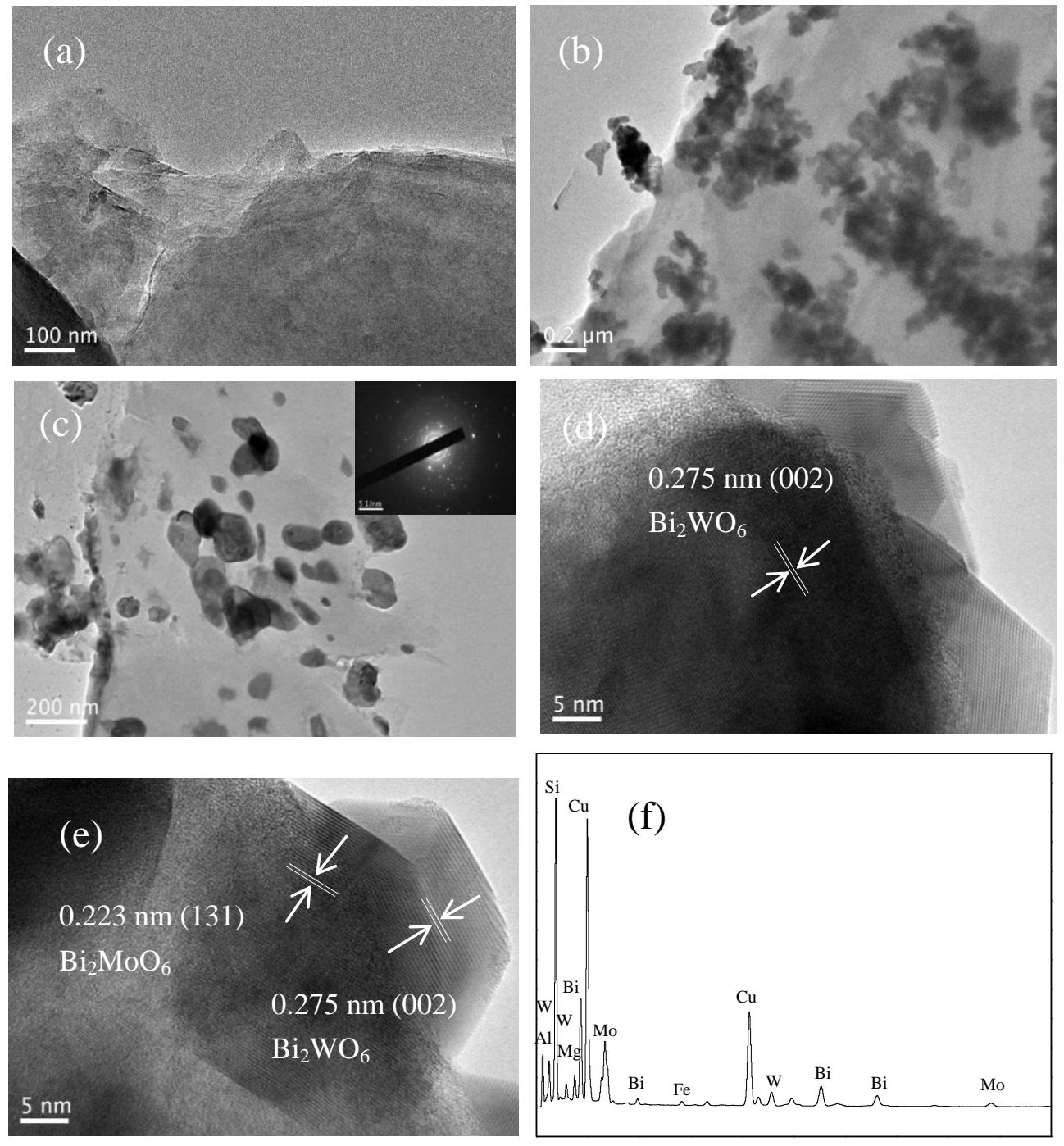

$\mathrm{E} / \mathrm{keV}$ 
Fig.3. TEM photographs of MMT (a), composite without pretreatment (b), composite with pretreatment (c), HRTEM of the $\mathrm{Bi}_{2} \mathrm{~W}_{0.7} \mathrm{Mo}_{0.3} \mathrm{O}_{6} / \mathrm{MMT}$ (d) and $\mathrm{Bi}_{2} \mathrm{~W}_{0.3} \mathrm{Mo}_{0.7} \mathrm{O}_{6} / \mathrm{MMT}(\mathrm{e})$, and its EDS pattern (f).

\subsection{UV-vis analysis}

Fig.4 displays the UV-vis spectra of $\mathrm{Bi}_{2} \mathrm{MoO}_{6} / \mathrm{MMT} \mathrm{Bi}_{2} \mathrm{WO}_{6} / \mathrm{MMT}$, $\mathrm{Bi}_{2} \mathrm{~W}_{0.7} \mathrm{Mo}_{0.3} \mathrm{O}_{6} / \mathrm{MMT}$ and $\mathrm{Bi}_{2} \mathrm{~W}_{0.3} \mathrm{Mo}_{0.7} \mathrm{O}_{6} / \mathrm{MMT}$ composites. The composites exhibit enhanced visible light responsible ability with Mo doping, which alters the band gap of the nanocomposites leading to red shift of absorption edge. It should be noted that the $\mathrm{Bi}_{2} \mathrm{~W}_{0.3} \mathrm{Mo}_{0.7} \mathrm{O}_{6} / \mathrm{MMT}$ sample shows higher absorption edge than $\mathrm{Bi}_{2} \mathrm{~W}_{0.7} \mathrm{Mo}_{0.3} \mathrm{O}_{6} / \mathrm{MMT}$ which suggests that when $\mathrm{x}$ is higher than 0.5 , there are substantial interaction between $\mathrm{Bi}_{2} \mathrm{MoO}_{6}$ and $\mathrm{Bi}_{2} \mathrm{~W}_{1-\mathrm{x}} \mathrm{Mo}_{\mathrm{x}} \mathrm{O}_{6}$ which may enhance the separation rate of photogenerated carriers.

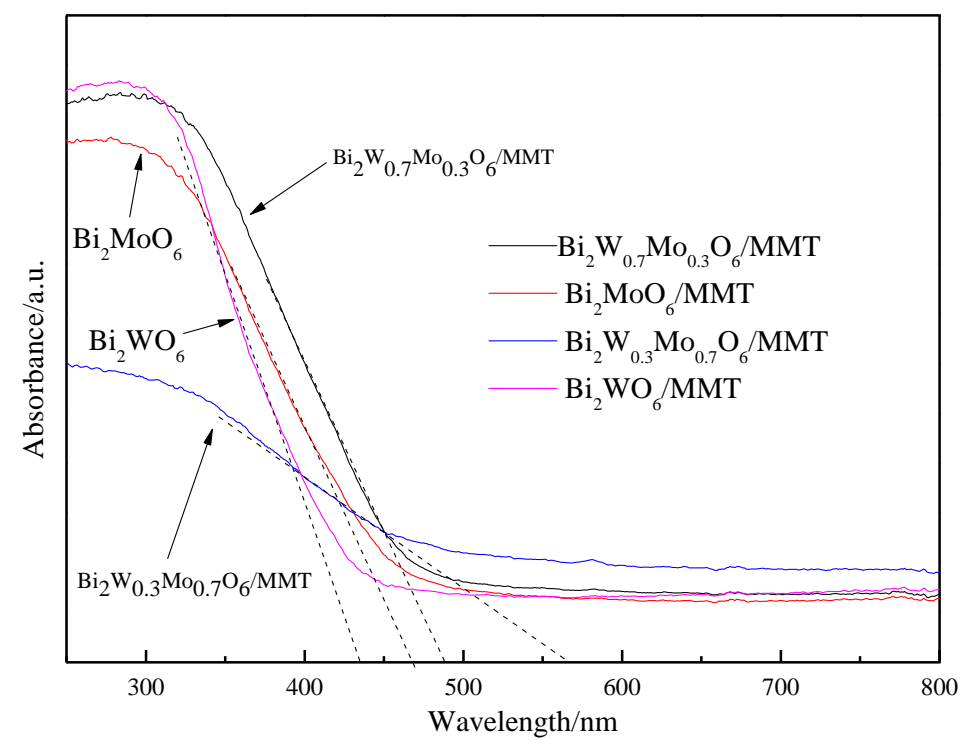

Fig. 4. UV-vis spectra of $\mathrm{Bi}_{2} \mathrm{MoO}_{6} / \mathrm{MMT}, \mathrm{Bi}_{2} \mathrm{WO}_{6} / \mathrm{MMT}$, $\mathrm{Bi}_{2} \mathrm{~W}_{0.7} \mathrm{Mo}_{0.3} \mathrm{O}_{6} / \mathrm{MMT}$ and $\mathrm{Bi}_{2} \mathrm{~W}_{0.3} \mathrm{Mo}_{0.7} \mathrm{O}_{6} / \mathrm{MMT}$. 


\subsection{FT-IR analysis}

Fig.5 demonstrates the FT-IR spectra of the composites. The band situated at $3430 \mathrm{~cm}^{-1}$ is corresponded to $-\mathrm{OH}$ stretching vibration of the water on the surface of MMT. The band located at $1641 \mathrm{~cm}^{-1}$ is consistent with $-\mathrm{OH}$ bending vibration in MMT [34]. Si-O stretching vibration appeares in $1050 \mathrm{~cm}^{-1}$ and $1099 \mathrm{~cm}^{-1}$ [35]. The bands located in the range of $900-1700 \mathrm{~cm}^{-1}$ and $650-910 \mathrm{~cm}^{-1}$ are respectively ascribed to the stretching vibration of $\mathrm{W}-\mathrm{O}$ and $\mathrm{Mo}-\mathrm{O}[36,37]$. Comparing the spectra of $\mathrm{Bi}_{2} \mathrm{~W}_{0.3} \mathrm{Mo}_{0.7} \mathrm{O}_{6} / \mathrm{MMT}$ and MMT, a new band at $672 \mathrm{~cm}^{-1}$ is identified which can be consistent with $\mathrm{Bi}-\mathrm{O}$ stretching vibration [38], implying the presence of $\mathrm{Bi}_{2} \mathrm{~W}_{1-\mathrm{x}} \mathrm{Mo}_{\mathrm{x}} \mathrm{O}_{6}$ on the MMT surface, which is similar to the XRD analysis.

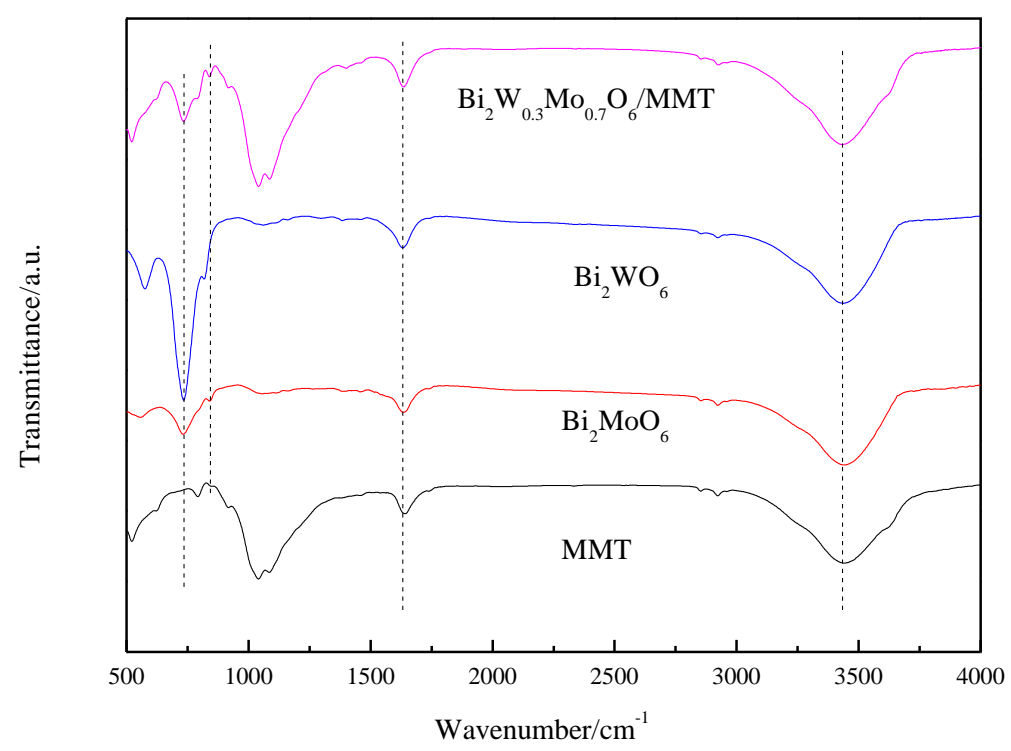

Fig. 5. FT-IR spectra of MMT, $\mathrm{Bi}_{2} \mathrm{WO}_{6}, \mathrm{Bi}_{2} \mathrm{MoO}_{6}, \mathrm{Bi}_{2} \mathrm{~W}_{0.3} \mathrm{Mo}_{0.7} \mathrm{O}_{6} / \mathrm{MMT}$

\subsection{PL analysis}

The separation rate of photogenerated carriers is revealed by PL 
spectra as displayed in Fig.6. It is well known that the separation efficiency of the photogenerated carriers is inversely proportional to the PL emission intensity. Therefore, the weaker PL emission intensity is, the higher separation efficiency and photocatalytic desulfurization are. The emission intensity of $\mathrm{Bi}_{2} \mathrm{WO}_{6} / \mathrm{MMT}$ locates at $460 \mathrm{~nm}$ is the strongest, indicating high recombination rate of photogenerated carriers [39]. The separation of electron-hole pairs is relatively increased due to Mo doping which weakens the emission intensity of composites. The heterostructure constructed by $\mathrm{Bi}_{2} \mathrm{~W}_{1-\mathrm{x}} \mathrm{Mo}_{\mathrm{x}} \mathrm{O}_{6}$ and $\mathrm{Bi}_{2} \mathrm{MoO}_{6}$ improves separation rate of photogenerated carriers when $\mathrm{x}$ reaches 0.6 . In addition, the other three peaks are ascribed to surface oxygen vacancies and defects [40].

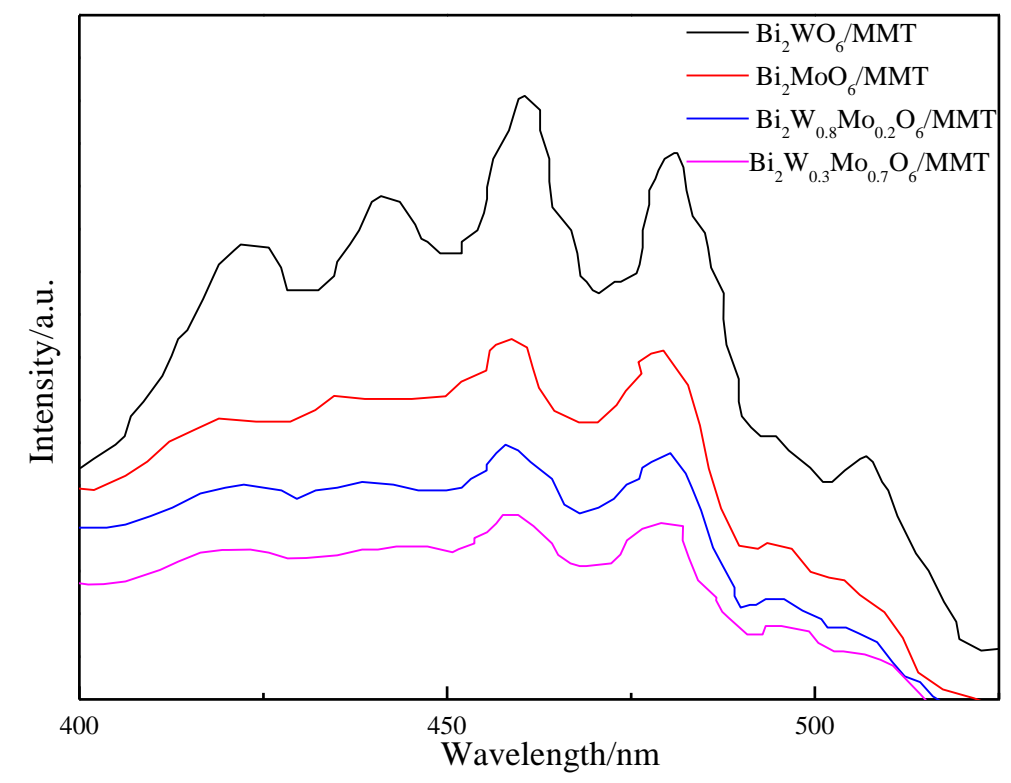

Fig. 6. PL spectra of $\mathrm{Bi}_{2} \mathrm{WO}_{6} / \mathrm{MMT}, \mathrm{Bi}_{2} \mathrm{MoO}_{6} / \mathrm{MMT}, \mathrm{Bi}_{2} \mathrm{~W}_{0.8} \mathrm{Mo}_{0.2} \mathrm{O}_{6} / \mathrm{MMT}$ and $\mathrm{Bi}_{2} \mathrm{~W}_{0.3} \mathrm{Mo}_{0.7} \mathrm{O}_{6} / \mathrm{MMT}$.

\subsection{XPS analysis}

The elemental compositions and chemical valence state of 
$\mathrm{Bi}_{2} \mathrm{~W}_{0.3} \mathrm{Mo}_{0.7} \mathrm{O}_{6} / \mathrm{MMT}$ are measured by XPS. Fig. 7a shows the survey scan of the sample indicating the existence of $\mathrm{Al}, \mathrm{Si}, \mathrm{O}, \mathrm{Bi}, \mathrm{Mo}$ and $\mathrm{W}$ elements, which is consistent with the EDS results. Bi $4 \mathrm{f}$ observed at $159.4 \mathrm{eV}$ and $164.1 \mathrm{eV}$ are ascribed to $\mathrm{Bi}^{3+}$ as shown in Fig. $7 \mathrm{~b}$. The peaks of Mo $3 \mathrm{~d}$ at $232.5 \mathrm{eV}$ and $235.4 \mathrm{eV}$ and $\mathrm{W} 4 \mathrm{f}$ at $35.3 \mathrm{eV}$ and 37.8 eV shown in Fig. 7c and Fig. 7d reveal the chemical valence state for $\mathrm{Mo}^{6+}$ and $\mathrm{W}^{6+}[23]$. The XPS result gives that the actual concentration of $\mathrm{Bi}, \mathrm{W}$ and $\mathrm{Mo}$ is $1.94 \%, 0.36 \%$ and $0.62 \%$ in the sample, which is close to the nominal concentration of each element for $\mathrm{Bi}_{2} \mathrm{~W}_{0.3} \mathrm{Mo}_{0.7} \mathrm{O}_{6}$. The actual concentration of $\mathrm{O}$ is $46.36 \%$ which originates from $\mathrm{Bi}_{2} \mathrm{~W}_{0.3} \mathrm{Mo}_{0.7} \mathrm{O}_{6}$ and MMT. As for MMT, the actual concentrations of Si, $\mathrm{Mg}$ and $\mathrm{Al}$ are $10.53 \%, 4.06 \%$ and $4.8 \%$, which are similar to their corresponding nominal concentration. In addition, the concentration of $\mathrm{C}$ located at $284.4 \mathrm{eV}$ reaches $31.33 \%$ which is ascribed to the adventitious hydrocarbon in the XPS apparatus.
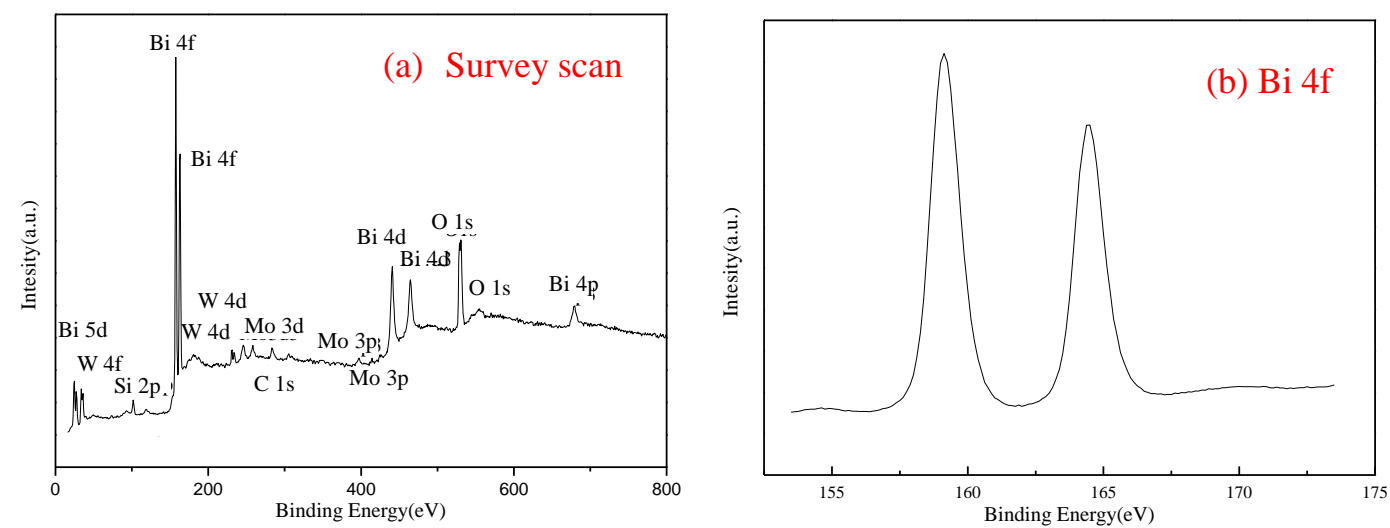

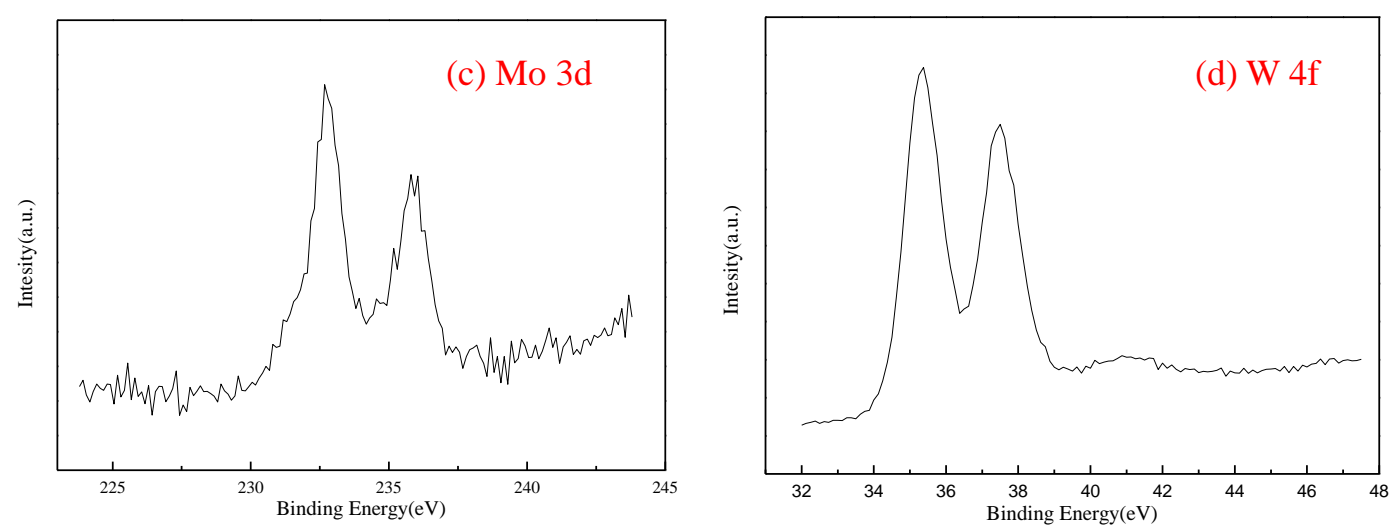

Fig.7. XPS spectra of $\mathrm{Bi}_{2} \mathrm{~W}_{0.3} \mathrm{Mo}_{0.7} \mathrm{O}_{6} / \mathrm{MMT}$ : Survey scan (a), Bi 4f (b), Mo 3d (c), W 4f (d).

\subsection{Catalytic properties}

The desulfurization of DBT is investigated utilizing various composites as catalyst. As shown in Fig. 8, the degradation rate is only 7\% with $\mathrm{H}_{2} \mathrm{O}_{2}$ in the photocatalytic system. By adding MMT, the desulfurization rate increase up to $17.2 \%$ which may be ascribed to the adsorption of MMT with DBT molecules. The degradation rate is increased by the addition of other composites. Pure $\mathrm{Bi}_{2} \mathrm{WO}_{6}$ and $\mathrm{Bi}_{2} \mathrm{MoO}_{6}$ both have low degradation rate for DBT. Meanwhile, $\mathrm{Bi}_{2} \mathrm{~W}_{1-\mathrm{x}} \mathrm{Mo}_{\mathrm{x}} \mathrm{O}_{6} / \mathrm{MMT}$ greatly improves the degradation rate for DBT. The possible reason is that Mo doping forms the solid solution phase of $\mathrm{Bi}_{2} \mathrm{~W}_{1-\mathrm{x}} \mathrm{Mo}_{\mathrm{x}} \mathrm{O}_{6}$, contributing to the red shift phenomenon compared with pure $\mathrm{Bi}_{2} \mathrm{WO}_{6}$ and $\mathrm{Bi}_{2} \mathrm{MoO}_{6}$ as seen in Fig. 4. Therefore, the visible light responsible ability of the composites is remarkably improved. Meanwhile, 
the heterostructure developed by $\mathrm{Bi}_{2} \mathrm{~W}_{1-\mathrm{x}} \mathrm{Mo}_{\mathrm{x}} \mathrm{O}_{6}$ and $\mathrm{Bi}_{2} \mathrm{MoO}_{6}$ improves photocatalytic properties of composites.

Fig. 9 shows the desulfurization rate with various Mo doping. It is not hard to find that the desulfurization rate of model oil is enhanced gradually along with the increase of Mo content when $\mathrm{x}$ is less than 0.7 . According to the XRD and Raman results, $\mathrm{Bi}_{2} \mathrm{~W}_{1-\mathrm{x}} \mathrm{Mo}_{\mathrm{x}} \mathrm{O}_{6}$ solid solution phase is formed when $\mathrm{x}$ is less than 0.5. However, the presence of $\mathrm{Bi}_{2} \mathrm{MoO}_{6}$ generates heterostructure with $\mathrm{Bi}_{2} \mathrm{~W}_{1-\mathrm{x}} \mathrm{Mo}_{\mathrm{x}} \mathrm{O}_{6}$ which may accelerate separation of photogenerated electron-hole pairs when $\mathrm{x}$ is higher than 0.5 . As a consequence, photocatalytic property is improved, and the highest desulfurization rate can reach up to $95 \%$. Nevertheless, when $\mathrm{x}$ is 0.8 or higher, the abnormal aggregation of $\mathrm{Bi}_{2} \mathrm{MoO}_{6}$ may restrain the transfer of photogenerated electrons, resulting in the decreased photocatalytic ability.

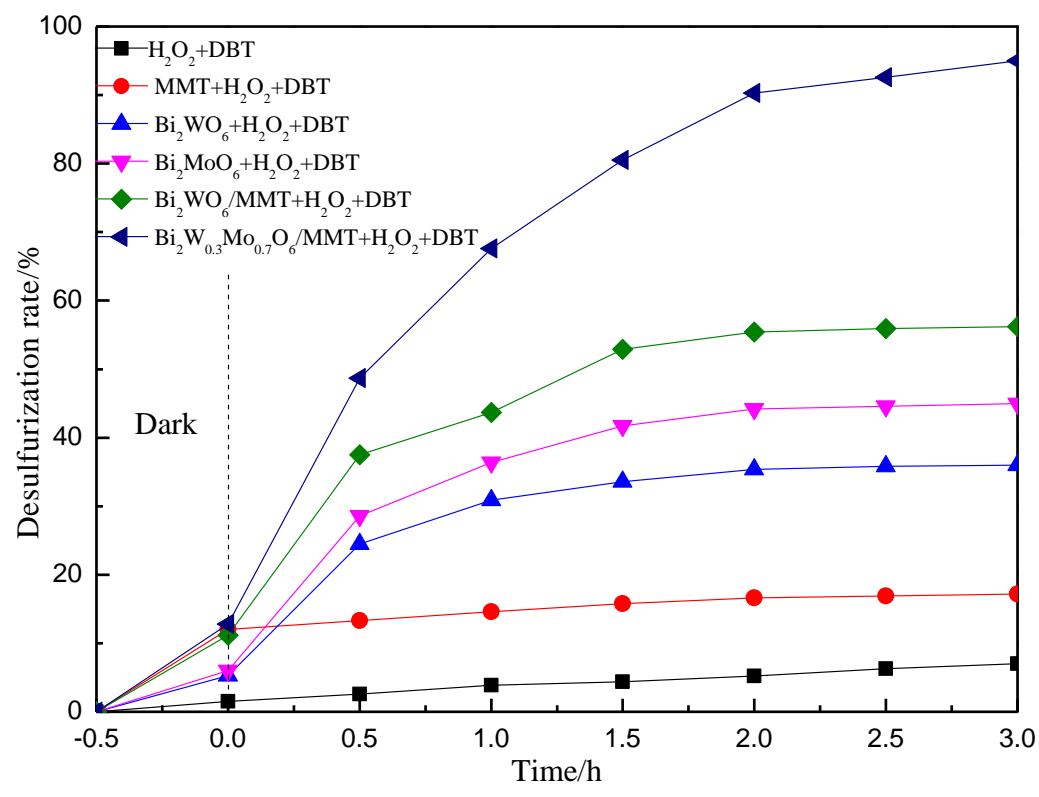


Fig. 8. Comparison of photocatalytic desulfurization of model oil by various composites.

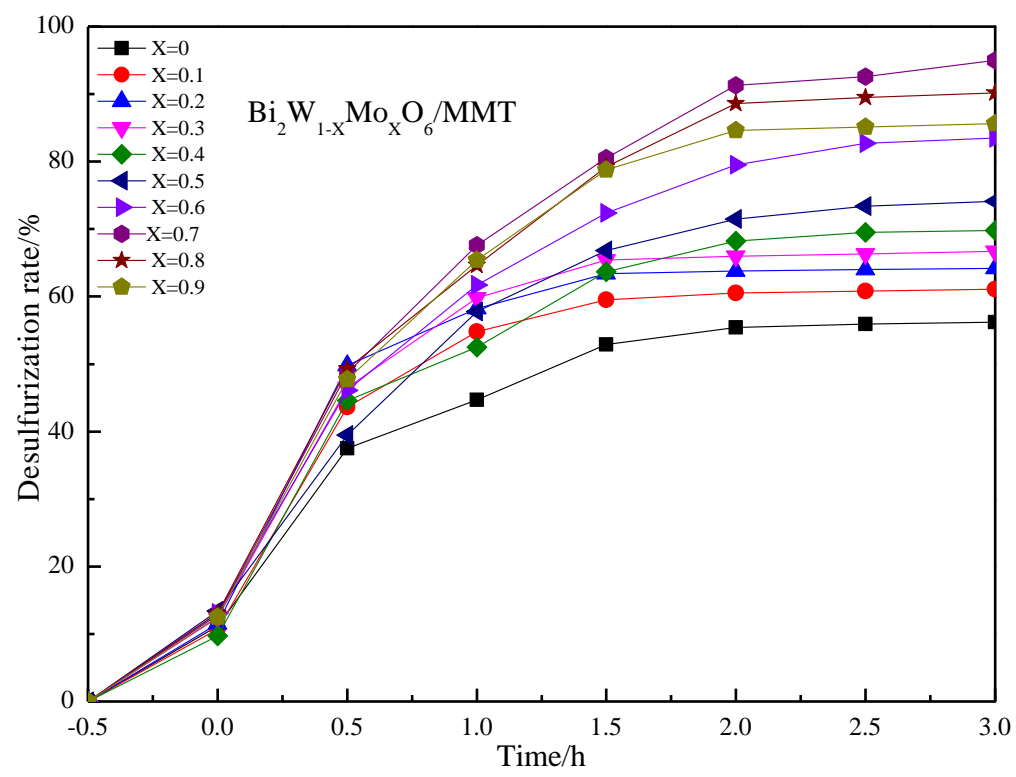

Fig. 9. Photocatalytic desulfurization of model oil by $\mathrm{Bi}_{2} \mathrm{~W}_{1-\mathrm{x}} \mathrm{Mo}_{\mathrm{x}} \mathrm{O}_{6} / \mathrm{MMT}$ with various molar fractions of Mo.

\subsection{Photocatalytic desulfurization mechanism}

In order to verify the radicals of nanocomposites in the process of photocatalysis, three different kinds of captors, triethanolamine (TEOA; $\mathrm{h}^{+}$scavenger), tert-butyl alcohol (TBA; a $\cdot \mathrm{OH}$ radical scavenger) and benzoquinone (BQ; a $\bullet \mathrm{O}_{2}^{-}$radical scavenger) are used. As shown in Fig. 10, the desulfurization rate of photocatalysts decreases slightly corresponding to the adding of TEOA and $\mathrm{BQ}$. It is found that the desulfurization rate of $\mathrm{Bi}_{2} \mathrm{~W}_{0.3} \mathrm{Mo}_{0.7} \mathrm{O}_{6} / \mathrm{MMT}$ has a remarkable decrease to $21.8 \%$, implying that $\cdot \mathrm{OH}$ plays an essential role during the photocatalytic reaction. The degradation products for one, two and three hours are detected by GC-MS shown in Fig. 11 respectively. It can be 
found that the obtained degradation products are almost the same compared with authentic $\mathrm{DBTO}_{2}$ in terms of the retention time and the mass spectrum. As the degradation time goes up, the content of DBT is decreased, on the contrary, the content of $\mathrm{DBTO}_{2}$ is increased, suggesting that DBT in model oil are almost transferred to $\mathrm{DBTO}_{2}$ after three hours of degradation. The photocatalytic mechanism is put forward according to the above results as shown in Fig. 12. The conduction band (CB) of $\mathrm{Bi}_{2} \mathrm{WO}_{6}$ is $0.22 \mathrm{eV}$ and valence band $(\mathrm{VB})$ is $3.0 \mathrm{eV}$, which is higher than $1.99 \mathrm{eV}$, where $-\mathrm{OH}$ can be oxidized to $\cdot \mathrm{OH}[20]$. The $\mathrm{CB}$ and VB $(-0.80$ $\mathrm{eV}$ and $1.86 \mathrm{eV}$ ) of $\mathrm{Bi}_{2} \mathrm{MoO}_{6}$ are more negative than $\mathrm{Bi}_{2} \mathrm{~W}_{1-\mathrm{x}} \mathrm{Mo}_{\mathrm{x}} \mathrm{O}_{6}$ [22]. As a consequence of this, $\mathrm{Bi}_{2} \mathrm{MoO}_{6}$ can be activated under visible light irradiation. Photogenerated electrons are rapidly transported to the surface of $\mathrm{Bi}_{2} \mathrm{~W}_{1-\mathrm{x}} \mathrm{Mo}_{\mathrm{x}} \mathrm{O}_{6}$. The electrons may react with $\mathrm{H}_{2} \mathrm{O}_{2}$ to form -OH. Finally, those adsorbed DBT moleculars on the MMT surface will be further oxidized to $\mathrm{DBTO}_{2}$ by the $\cdot \mathrm{OH}$ radicals due to its strong oxidation ability. On account of the above statement, we presented the following reaction equations:

$$
\begin{aligned}
& \mathrm{Bi}_{2} \mathrm{~W}_{1-\mathrm{x}} \mathrm{Mo}_{\mathrm{x}} \mathrm{O}_{6} / \mathrm{MMT}+\mathrm{h} v \rightarrow \mathrm{e}^{-}+\mathrm{h}^{+} \\
& \mathrm{e}^{-}+\mathrm{H}_{2} \mathrm{O}_{2} \rightarrow \cdot \mathrm{OH}+\mathrm{OH}^{-} \\
& \mathrm{h}^{+}+\mathrm{OH}^{-} \rightarrow \cdot \mathrm{OH} \\
& \mathrm{DBT}+\cdot \mathrm{OH} \rightarrow \mathrm{DBTO}_{2}
\end{aligned}
$$




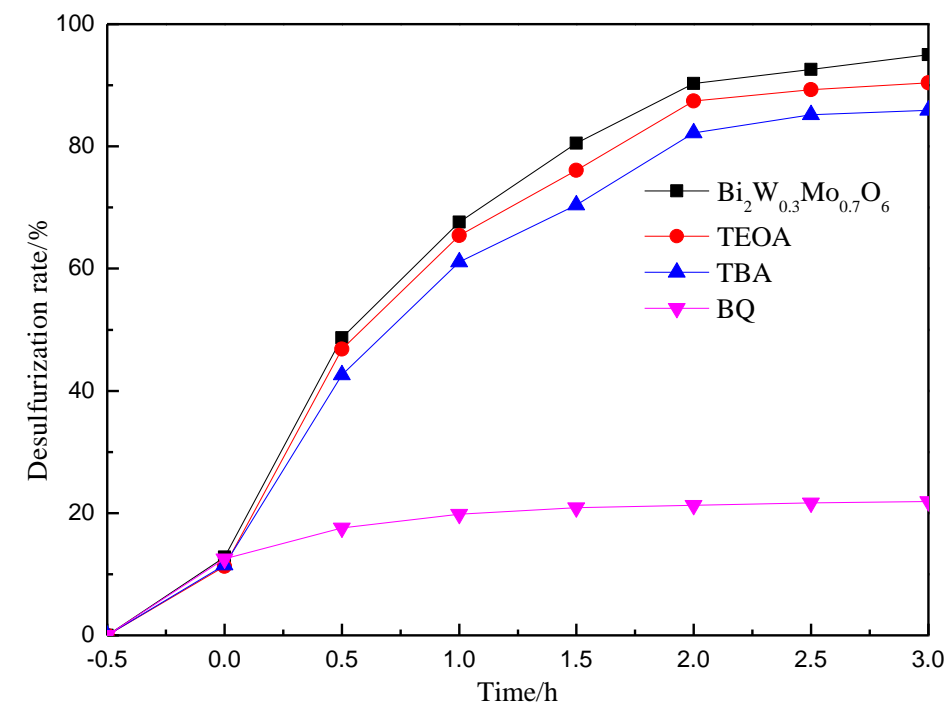

Fig. 10. Photocatalytic desulfurization with adding different quenching agents.

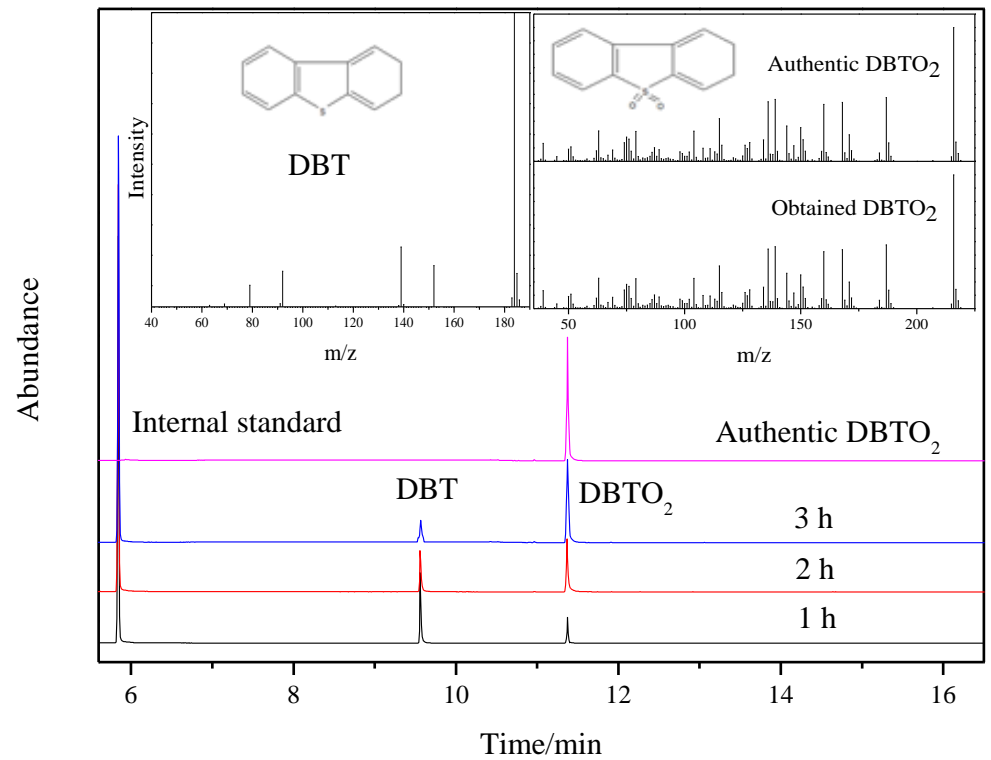

Fig. 11. GC-MS analysis of the authentic $\mathrm{DBTO}_{2}$ and the degradation products for one two and three hours of the model oil. 


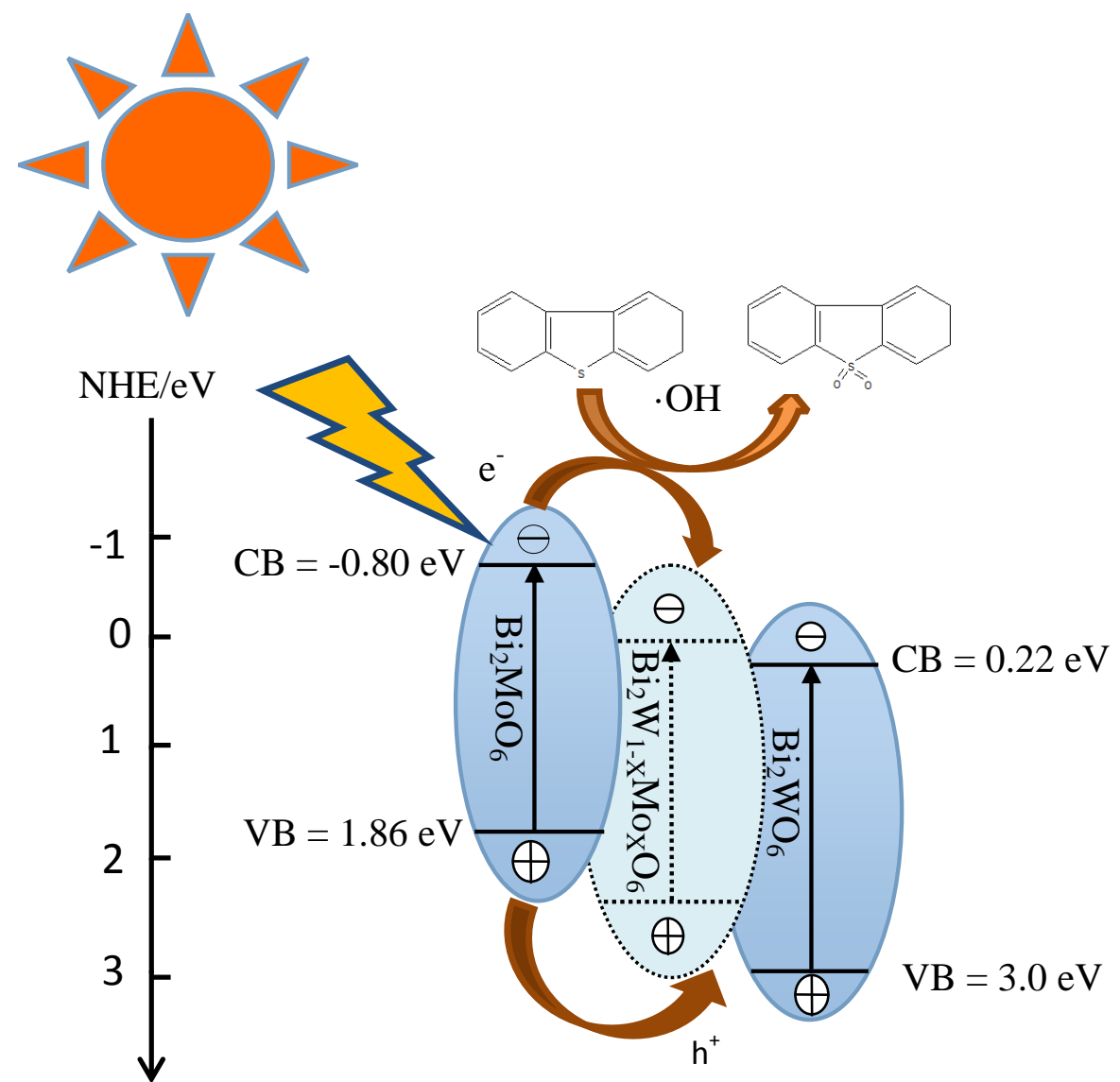

Fig. 12. Photocatalytic desulfurization mechanism of $\mathrm{Bi}_{2} \mathrm{~W}_{1-\mathrm{x}} \mathrm{Mo}_{\mathrm{x}} \mathrm{O}_{6} / \mathrm{MMT}$

\subsection{Analysis of recycled catalysts}

The repeated desulfurization experiment of recycled catalyst is performed. After five recycle times, the desulfurization rate still remains more than $90 \%$, indicating that the recycled catalyst has an outstanding stability. The recycling process is easy to execute, and no extra process is added. After desulfurization reaction, catalysts are separated by centrifugation to remove model oil and $\mathrm{H}_{2} \mathrm{O}_{2}$, followed by drying to obtain the recycled catalyst. XRD and FT-IR characterizations are employed to compare the recycled catalyst and fresh catalyst. In Fig. 13, 
the main peaks of $\mathrm{W}-\mathrm{O}$ band and Mo-O band still can be found, suggesting that the structure of $\mathrm{Bi}_{2} \mathrm{~W}_{0.3} \mathrm{Mo}_{0.7} \mathrm{O}_{6} / \mathrm{MMT}$ has not changed. However, a new peak locates at $583.5 \mathrm{~cm}^{-1}$ in the recycled catalyst can be identified, which may be ascribed to the $\mathrm{S}=\mathrm{O}$ band due to the fact that the DBT in the mode oil is oxidized to $\mathrm{DBTO}_{2}$. As shown in Fig.14, new miscellaneous peaks can be ascribed to the DBT-sulfone and trace amount of residual DBT, which further prove the conversion of DBT [41].

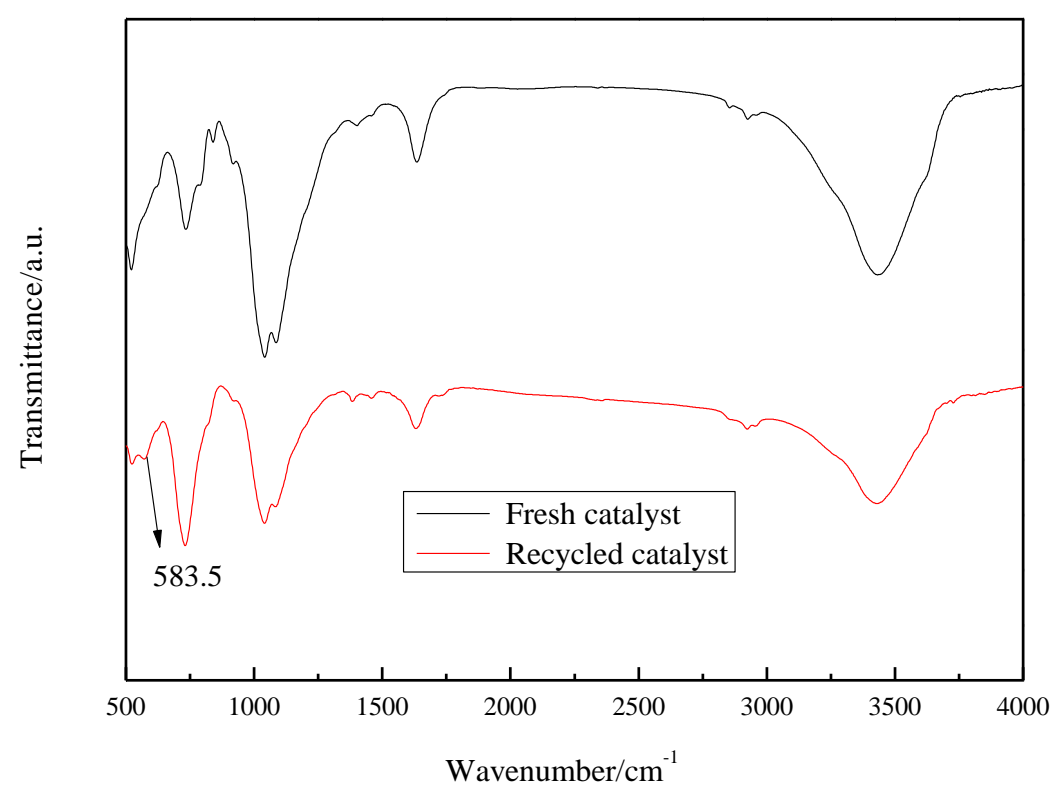

Fig. 13. FT-IR spectra of fresh catalyst and recycled catalyst. 


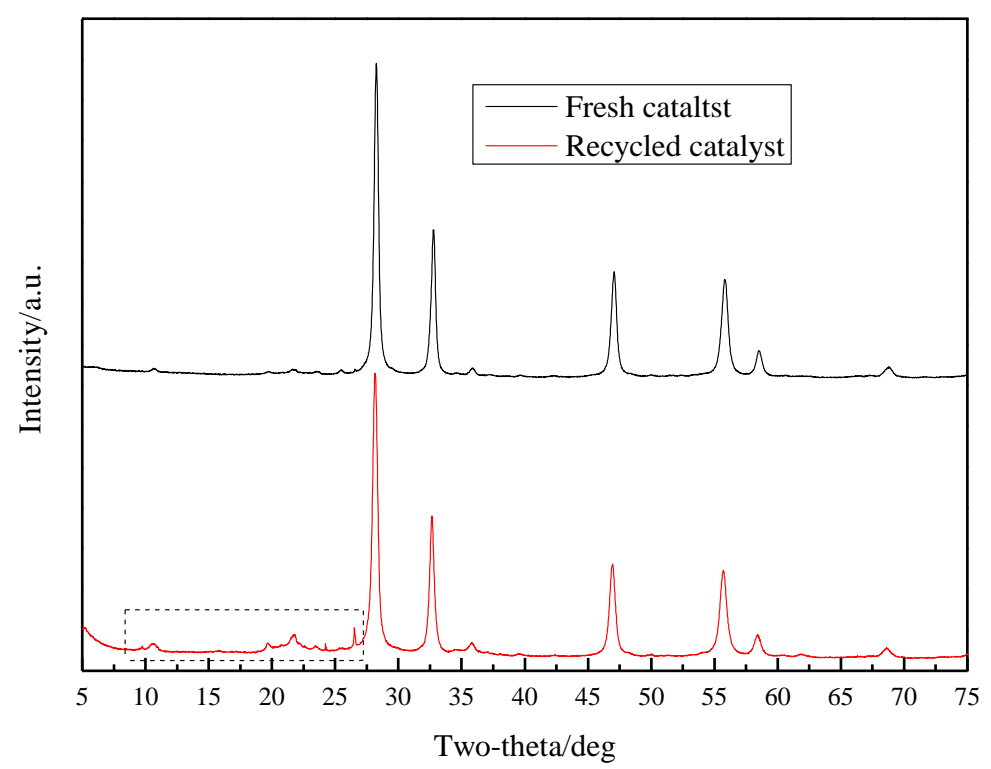

Fig. 14. XRD patterns of fresh catalyst and recycled catalyst.

\section{Conclusions}

In this work, $\mathrm{Bi}_{2} \mathrm{~W}_{1-\mathrm{x}} \mathrm{Mo}_{\mathrm{x}} \mathrm{O}_{6} / \mathrm{MMT}$ nanocomposites have been successfully synthesized via a facile one-pot hydrothermal method. $\mathrm{Bi}_{2} \mathrm{~W}_{1-\mathrm{x}} \mathrm{Mo}_{\mathrm{x}} \mathrm{O}_{6} / \mathrm{MMT}$ demonstrates remarkable visible light catalytic performance for oxidizing DBT due to the formation of $\mathrm{Bi}_{2} \mathrm{~W}_{1-\mathrm{x}} \mathrm{Mo}_{\mathrm{x}} \mathrm{O}_{6} / \mathrm{Bi}_{2} \mathrm{MoO}_{6}$ coherent heterostructure which improves the visible light absorption efficiency and the separation rate of photogenerated carriers. Radicals trapping experiments identify that $\cdot \mathrm{OH}$ radicals play an indispensable role in the photocatalytic oxidative desulfurization. The highest desulfurization rate of $95 \%$ for the model oil was achieved when $\mathrm{x}$ is 0.7 for $3 \mathrm{~h} . \mathrm{Bi}_{2} \mathrm{~W}_{1-\mathrm{x}} \mathrm{Mo}_{\mathrm{x}} \mathrm{O}_{6} / \mathrm{MMT}$ nanocomposite is anticipated to bring promising application in deep desulfurization or other environmental abatement areas. 


\section{Acknowledgments}

This work was supported by the National Science Foundation of China (51674043, 51478285), Priority Academic Program Development of Jiangsu Higher Education Institutions (PAPD), Jiangsu Technology Support Program (BE2014100, BE2015103) and Jiangsu International Cooperation Project (BZ2015040).

\section{References}

[1] D. Piccinino, I. Abdalghani, G. Botta, M. Crucianelli, M. Passacantando, M.L.D. Vacri, R. Saladino, Preparation of wrapped carbon nanotubes poly(4-vinylpyridine)/MTO based heterogeneous catalysts for the oxidative desulfurization (ODS) of model and synthetic diesel fuel, Appl. Catal. B 200 (2017) 392-401.

[2] C.T. Guo, S.L. Jin, X.L. Wang, Y.H. Mu, J.L. Cheng, R. Zhang, M.L. Jin, Promoting effect of surface acidities on efficiency of copper modifier for ordered mesoporous carbon- $\mathrm{SiO}_{2}-\mathrm{Al}_{2} \mathrm{O}_{3}$ nanocomposites in adsorptive desulfurization, Micropor. Mesopor. Mat. 240 (2017) 197-204.

[3] X.Y. Zeng, X.Y. Xiao, Y. Li, J.Y. Chen, H.L. Wang, Deep desulfurization of liquid fuels with molecular oxygen through graphene photocatalytic oxidation, Appl. Catal. B 209 (2017) 98-109.

[4] L. Wang, W.Y. Wang, N. Mominou, L.X. Liu, S.Z. Li, Ultra-deep Desulfurization of Gasoline through Aqueous Phase in-situ 
Hydrogenation and Photocatalytic Oxidation, Appl. Catal. B 193 (2016) 180-188.

[5] W.J. Jiang, D. Zheng, S.H. Xun, Y.J. Qin, Q.Q. Lu, W.S. Zhu, H.M. Li, Polyoxometalate-based ionic liquid supported on graphite carbon induced solvent-free ultra-deep oxidative desulfurization of model fuels, Fuel 190 (2017) $1-9$.

[6] L. Zhang, W.Q. Fu, Q.Y. Yu, T.D. Tang, Y.C. Zhao, H.W. Zhao, Y.D. $\mathrm{Li}, \mathrm{Ni}_{2} \mathrm{P}$ clusters on zeolite nanosheet assemblies with high activity and good stability in the hydrodesulfurization of 4,6-dimethyldibenzothiophene, J. Catal. 338 (2016) 210-221.

[7] M.A. Alvarez-Amparán, L. Cedeño-Caero, $\mathrm{MoO}_{\mathrm{x}}-\mathrm{VO}_{\mathrm{x}}$ based catalysts for the oxidative desulfurization of refractory compounds: Influence of $\mathrm{MoO}_{\mathrm{x}}-\mathrm{VO}_{\mathrm{x}}$ interaction on the catalytic performance, Catal. Today, 282 (2017) 133-139.

[8] T.T. Wang, Y. Lu, H.L. Wu, E.B. Wang, Surfactant-encapsulated high-nuclear polyoxometalate complexes for catalytic oxidative desulfurization of model oil, Inorg. Chim. Acta 446 (2016) 13-18.

[9] C.P. Yang, K. Zhao, Y. Cheng, G.M. Zeng, M.M. Zhang, J.J. Shao, L. Lu, Catalytic oxidative desulfurization of BT and DBT from n-octane using cyclohexanone peroxide and catalyst of molybdenum supported on 4A molecular sieve, Sep. Purif. Technol. 163 (2016) 153-161.

[10] F.L. Yu, C.Y. Liu, B. Yuan, P.H. Xie, C.X. Xie, S.T. Yu, 
Energy-efficient extractive desulfurization of gasoline by polyether-based ionic liquids, Fuel 177 (2016) 39-45.

[11] M. Agarwal, P.K. Dikshit, J.B. Bhasarkar, A.J. Borah, V.S. Moholkar, Physical insight into ultrasound-assisted biodesulfurization using free and immobilized cells of Rhodococcus rhodochrous MTCC 3552, Chem. Eng. J. 295 (2016) 254-267.

[12] X.N. Sun, A.H.M.S. Hussain, M.Y. Chi, X.Q. Cheng, B.J. Tatarchuk, Persistent adsorptive desulfurization enhancement of $\mathrm{TiO}_{2}$ after one-time ex-situ UV-treatment, Fuel 193 (2017) 95-100.

[13] K.Y. Leng, Y.Y. Sun, X. Zhang, M. Yu, W. Xu, Ti-modified hierarchical mordenite as highly active catalyst for oxidative desulfurization of dibenzothiophene, Fuel 174 (2016) 9-16.

[14] M.A. Safa, R. Al-Majren, T. Al-Shamary, J.I. Park, X.L. Ma, Removal of sulfone compounds formed in oxidative desulfurization of middle distillate, Fuel 194 (2017) 123-128.

[15] X.W. Lu, X.Z. Li, J.C. Qian, N.M. Miao, C. Yao, Z.G. Chen, Synthesis and characterization of $\mathrm{CeO}_{2} / \mathrm{TiO}_{2}$ nanotube arrays and enhanced photocatalytic oxidative desulfurization performance, J. Alloys Compd. 661 (2016) 363-371.

[16] S. Mandizadeh, M. Salavati-Niasari, M. Sadri, Hydrothermal synthesis, characterization and magnetic properties of $\mathrm{BaFe}_{2} \mathrm{O}_{4}$ nanostructure as a photocatalytic oxidative desulfurization of 
dibenzothiophene, Sep. Purif. Technol. 175 (2017) 399-405.

[17] S.Y. Dong, X.H. Ding, T. Guo, X.P. Yue, X. Han, J.H. Sun, Self-assembled hollow sphere shaped $\mathrm{Bi}_{2} \mathrm{WO}_{6} / \mathrm{RGO}$ composites for efficient sunlight-driven photocatalytic degradation of organic pollutants, Chem. Eng. J. 316 (2017) 778-789.

[18] S. Issarapanacheewin, K. Wetchakun, S. Phanichphant, W. Kangwansupamonkon, N. Wetchakun, Efficient photocatalytic degradation of Rhodamine $\mathrm{B}$ by a novel $\mathrm{CeO}_{2} / \mathrm{Bi}_{2} \mathrm{WO}_{6}$ composite film, Catal. Today 278 (2016) 280-290.

[19] S. Issarapanacheewin, K. Wetchakun, S. Phanichphant, W. Kangwansupamonkon, N. Wetchakun, Photodegradation of organic dyes by $\mathrm{CeO}_{2} / \mathrm{Bi}_{2} \mathrm{WO}_{6}$ nanocomposite and its physicochemical properties investigation, Ceram. Int. 42 (2016) 16007-16016.

[20] J. Zhang, L.H. Huang, L.X. Yang, Z.D. Lu, X.Y. Wang, G.L. Xu, E.P. Zhang, H.B. Wang, Z. Kong, J.H. Xi, Controllable synthesis of $\mathrm{Bi}_{2} \mathrm{WO}_{6}$ $(001) / \mathrm{TiO}_{2}(001)$ heterostructure with enhanced photocatalytic activity, J. Alloys Compd. 676 (2016) 37-45.

[21] X.N. Liu, Q.F. Lu, J.H. Liu, Electrospinning preparation of one-dimensional $\mathrm{ZnO} / \mathrm{Bi}_{2} \mathrm{WO}_{6}$ heterostructured sub-microbelts with excellent photocatalytic performance, J. Alloys Compd. 662 (2016) 598-606.

[22] S.Y. Wang, X.L. Yang, X.H. Zhang, X. Ding, Z.X. Yang, K. Dai, H. 
Chen, A plate-on-plate sandwiched Z-scheme heterojunction photocatalyst: $\quad \mathrm{BiOBr}-\mathrm{Bi}_{2} \mathrm{MoO}_{6}$ with enhanced photocatalytic performance, Appl. Surf. Sci. 391 (2017) 194-201.

[23] F.J. Zhang, S.F. Zhu, F.Z. Xie, J. Zhang, Z.D. Meng, Plate-on-plate structured $\mathrm{Bi}_{2} \mathrm{MoO}_{6} / \mathrm{Bi}_{2} \mathrm{WO}_{6}$ heterojunction with high-efficiently gradient charge transfer for decolorization of MB, Sep. Purif. Technol. 113 (2013) $1-8$.

[24] X.Z. Li, Z.S. Zhang, C. Yao, X.W. Lu, X.B. Zhao, C.Y. Ni, Attapulgite- $\mathrm{CeO}_{2} / \mathrm{MoS}_{2}$ ternary nanocomposite for photocatalytic oxidative desulfurization, Appl. Surf. Sci. 364 (2015) 589-596.

[25] Y. Liu, D. Zhang, Synergetic effect in the multifunctional composite film of graphene- $\mathrm{TiO}_{2}$ with transparent conductive, photocatalytic and strain sensing properties, J. Alloys Compd. 698 (2017) 60-67.

[26] A. Mishra, A. Mehta, M. Sharma, S. Basu, Enhanced heterogeneous photodegradation of VOC and dye using microwave synthesized $\mathrm{TiO}_{2}$ /Clay nanocomposites: A comparison study of different type of clays, J. Alloys Compd. 694 (2017) 574-580.

[27] I.H.A.E. Maksod, T.S. Saleh, E.Z. Hegazy, Preparation, characterization and utilization of $(\mathrm{Ni}: \mathrm{Cu})$ bimetallic system loaded on zeolites, J. Alloys Compd. 506 (2010) 923-927.

[28] S. Sohrabnezhad, A. Pourahmad, T. Salavatiyan, CuO-MMT nanocomposite: effective photocatalyst for the discoloration of methylene 
blue in the absence of $\mathrm{H}_{2} \mathrm{O}_{2}$, Appl. Phys. A 122 (2016) 1-12.

[29] L.F. Sun, Y.Y. Ding, Y.L. Jiang, Q.Y. Liu, Montomorillonite-loaded ceria nanocomposites with superior peroxidase-like activity for rapid colorimetric detection of $\mathrm{H}_{2} \mathrm{O}_{2}$, Sensor. Actuat. B 239 (2017) 848-856.

[30] B.R. Wu, L.H. Su, D.H. Dai, X.L. Chai, Develpoment of montomorillonite-supported nano $\mathrm{CaO}_{2}$ for enhanced denatering of waste-activated sludge by synergistic effect of filtration aid and peroxidation, Chem. Eng. J. 307 (2017) 418-426.

[31] H.Q. Li, Y.M. Cui, W.S. Hong, High photocatalytic performance of $\mathrm{BiOI} / \mathrm{Bi}_{2} \mathrm{WO}_{6}$ toward toluene and Reactive Brilliant Red, Appl. Surf. Sci.264 (2013) 581-588.

[32] C.M. Li, G. Chen, J.X. Sun, J.C. Rao, Z.H. Han, Y.D. Hu, W.N. Xing, C.M. Zhang, Doping effect of phosphate in $\mathrm{Bi}_{2} \mathrm{WO}_{6}$ and universal improved photocatalytic activity for removing various pollutants in water, Appl. Catal. B 188 (2016) 39-47.

[33] J.P. Zou, J. Ma, Q. Huang, S.L. Luo, J. Yu, X.B. Luo, W.L. Dai, J. Sun, G.C. Guo, C.T. Au, Graphene oxide as structure-directing and morphology-controlling agent for the syntheses of heterostructured graphene- $\mathrm{Bi}_{2} \mathrm{MoO}_{6} / \mathrm{Bi}_{3.64} \mathrm{Mo}_{0.3} 6 \mathrm{O}_{6.55}$ composites with high photocatalytic activity, Appl. Catal. B 156-157 (2014) 447-455.

[34] Z.J. Huang, P.X. Wu, B.N. Gong, S.S. Yang, H.L. Li, Z. Zhu, L.H. Cui, Preservation of glutamic acid-iron chelate into montmorillonite to 
efficiently degrade Reactive Blue 19 in a Fenton system under sunlight irradiation at neutral pH, Appl. Surf. Sci. 370 (2016) 209-217.

[35] A. Rapaczkmita, M.M. Bućko, E. Stodolakzych, M. Mikołajczyk, P. Dudek, M. Trybus, Characterisation, in vitro release study, and antibacterial activity of montmorillonite-gentamicin complex material, Mater. Sci. Eng. C 70 (2016) 471-478.

[36] T.Y. Wang, G.S. Xiao, C.Y. Li, S. Zhong, F.J. Zhang, One-step synthesis of a sulfur doped $\mathrm{Bi}_{2} \mathrm{WO}_{6} / \mathrm{Bi}_{2} \mathrm{O}_{3}$ composite with enhanced visible-light photocatalytic activity, Mater. Lett. 138 (2015) 81-84.

[37] H.P. Li, J.Y. Liu, W.G. Hou, N. Du, R.J. Zhang, X.T. Tao, Synthesis and characterization of $\mathrm{g}-\mathrm{C}_{3} \mathrm{~N}_{4} / \mathrm{Bi}_{2} \mathrm{MoO}_{6}$ heterojunctions with enhanced visible light photocatalytic activity, Appl. Catal. B 160-161 (2014) 89-97. [38] J.L. Lv, K. Dai, J.F. Zhang, L. Geng, C.H. Liang, Q.C. Liu, G.p. Zhu, C. Chen, Facile synthesis of Z-scheme graphitic- $\mathrm{C}_{3} \mathrm{~N}_{4} / \mathrm{Bi}_{2} \mathrm{MoO}_{6}$ nanocomposite for enhanced visible photocatalytic properties, Appl. Surf. Sci. 358 (2015) 377-384.

[39] Z.F. Zhu, Y. Yan, J.Q. Li, Preparation of flower-like $\mathrm{BiOBr}-\mathrm{WO}_{3}-\mathrm{Bi}_{2} \mathrm{WO}_{6}$ ternary hybrid with enhanced visible-light photocatalytic activity, J. Alloys Compd. 651 (2015) 184-192.

[40] Y.C. Yang, J.W. Wen, J.H. Wei, R. Xiong, J. Shi, C.X. Pan, Polypyrrole-decorated $\quad \mathrm{Ag}^{-\mathrm{TiO}_{2}}$ nanofibers exhibiting enhanced photocatalytic activity under visible-light illumination, ACS Appl. Mater. 
Inter. 5 (2013) 6201-6207.

[41] W.S. Zhu, B.L. Dai, P.W. Wu, Y.H. Chao, J. Xiong, S.H. Xun, H.P. Li, H.M. Li, Graphene-Analogue Hexagonal BN Supported with Tungsten-based Ionic Liquid for Oxidative Desulfurization of Fuels, ACS Sustain. Chem. Eng. 3 (2015) 186-194. 